\title{
Domestic measures during peace time for the implementation of International Humanitarian Law (IHL)
}

\author{
Mohammad Saidul Islam \\ Department of Laws \\ International Islamic University Chittagong (IIUC), Bangladesh
}

\begin{abstract}
International Humanitarian Law (IHL) is frequently neglected by the Parties to the Geneva Conventions during armed conflict (AC). In the contemporary world, IHL has been facing a great threat due to lack of proper implementation which resulted in the severe wounds, unnecessary sufferings, superfluous injury, and even death to the civilians, children, women, and combatants in and outside the armed field. For the implementation of IHL, it is essential that States must take proper steps during peace, conflict, and post-conflict time. The article presents the various mechanisms of implementation of IHL need to be taken by the States during the time of peace. It also focuses the most significant peace time steps sought to be taken by the State to make the IHL rules familiar to the civilians and combatant, to ensure the availability of the necessary instrumentalities for using those during AC for protection and minimization of the sufferings of the victims and to enact essential legislation for trial of the violators after the end of the conflict.
\end{abstract}

Keywords IHL, Implementation, Peace time measures, Preventive steps, Armed conflict

Paper type Literature review

\section{Introduction}

From the very beginning of the codification of IHL in early 1860s, it was sought to protect the protected persons and objects and to limit the sufferings of victims of armed conflict by protecting and assisting the victims and limiting the choice of weapons and war strategies. These underlying objects have not been properly achieved because of the poor implementation of IHL. Hope and relentless efforts are continuing to make effective implementation of IHL during peace and conflict time to protect those who are not taking part in hostilities and those who have become incapacitated due to wounds or sickness or other reasons. To give full 
effectiveness of IHL it is essential that the States must take effective steps during peace, conflict and post conflict time. The peace time measures are first and the most important steps of a State for limiting the combatants under the boundaries of the provisions of IHL during conflict time. If a State does not take any measures during peace time it will not be possible for the concerning State to conduct war complying with the principles of IHL. This paper highlights the steps that must be taken by a State during peace time to give appropriate effectiveness of IHL during conflict and post-conflict time.

\section{Definition of Implementation of IHL}

In general term "implementation" means all the measures which are to be taken by the States, individuals or other organizations to give full effectiveness of the IHL. Rajon (2008) says, taking prior steps to avoid the future violations of IHL is also called implementation but this concept is used in narrower sense where implementation is differentiated from enforcement steps taken to restore the observance where law has already been violated and ensuring compliance and respect as well (Draper, 1979:9). In wider sense implementation includes the means of prevention, means of control, means of sanctions and other means for the realization of full benefits of the IHL (Sandoz, 1997:250).

Here it should be noted that the term "implementation of IHL" encompasses all the measures which are to be taken during peace, war and post-war time for getting full benefit of IHL. It indicates that the State will have to take some preventive measures, i.e., making legislation containing the provisions of Geneva Conventions, disseminating the conventions and its protocols, translation of the conventions and additional protocols (AP) in her mother language, training to the military personnel etc., taking some controlling measures to compel the belligerents to comply with IHL during the conflict and need to take some enforcement measures immediately after the end of conflict to punish those who have already violated IHL.

\section{Peace time measures to implement IHL}

A wide range of measures need to be taken during peace, conflict and post conflict time for the implementation of IHL. Among these three staged steps, the peace measures help the State parties to the armed conflict to protect the protected persons and objects and to minimize the sufferings of the victims during AC. It means a State must take some steps at the time of peace so that if the State engages into any conflict then it can comply with the objectives and principles of IHL during the 
time of warfare and after the end of the hostilities. In this stage the States are to take some measures which are very much important for the implementation of IHL because without taking prior steps implementing IHL during armed conflict is impossible (Murphy, 2004). It is not sufficient merely to follow some rules when the conflict begins, but it requires that the States must take some measures both before starting the armed conflict and during the conflict and after the end of the conflict. For the implementation of IHL, preventive measures have considerable importance in many respects compared to other two stages of implementation of IHL. Firstly, without taking prior measures, it is quite impossible to implement IHL during armed conflict and secondly, punishing the violators after the end of war requires enacting law (International Committee of the Red Cross [ICRC]), establishing necessary court or tribunal and appointing necessary manpower during peace time.

States should take some measures during peace time namely (a) to make the civilians and combatants acquainted with the IHL, (b) to set up the necessary structures (c) to appoint required number of personnel and (d) to enact legislations for prosecuting the violators of IHL. With a view to achieving these objectives, the State is required "to respect and to ensure respect for the present conventions in all circumstances" (common article 1, GCs 1949) and some other additional activities under these conventions are required to be done. The following discussion focuses the activities what must be taken by a State during peace time to implement IHL at the time of AC and after the end of conflict.

\section{Development and acceptance of IHL instrumentalities by the States}

In the middle of the last century, IHL was quite unknown to the world communities. Even less than three decades ago, IHL was hardly known by people and few persons namely ICRC lawyers, military lawyers and so on (Murphy, 2004:47). It is mentionable that in 1970s only the University of Geneva offered a regular IHL course (National Implementation of IHL, 2010).

Today, the scenario has revolutionarily changed. Now people of all sectors either belligerents or politicians or lawyers or journalists or students or diplomats or terrorists or rebels, NGO activists, ICRC representatives, demonstrators, civilians populations and so on constantly refer IHL. And it is worthy to mention here that now IHL is offered in different levels of educations such as undergraduate, graduate and post graduate. This huge development of IHL both in documentations and on 
creating awareness among people has lessened the difficulties of implementation of IHL significantly. For implementation of IHL, sufficient international documents have already been adopted and now it needs to be implemented in national level by signing and ratifying those documents and simultaneously nationalizing those international documents by making State legislations.

Table 4: Table shows the States that have accepted IHL core documents (ICRC, 2015)

\begin{tabular}{|c|c|c|c|}
\hline SL. & Title & State parties & States ratified \\
\hline 1 & 1949 Geneva Conventions & 196 & 196 \\
\hline 2 & 1977 Additional Protocol I & 174 & 174 \\
\hline 3 & 1977 Additional Protocol II & 168 & 168 \\
\hline 4 & 2005 Additional Protocol III & 72 & 72 \\
\hline 5 & $\begin{array}{l}1954 \text { The Hague Convention for the } \\
\text { Protection of Cultural Property in Armed } \\
\text { Conflict }\end{array}$ & 126 & 4 \\
\hline 6 & $\begin{array}{l}1954 \text { Protocol I Concerning Cultural Property } \\
\text { in Situations of Occupation }\end{array}$ & 103 & 1 \\
\hline 7 & $\begin{array}{l}2000 \text { Optional Protocol on the Involvement of } \\
\text { Children in Armed Conflicts }\end{array}$ & 161 & 18 \\
\hline 8 & 1975 The Biological Weapons Convention & 173 & \\
\hline 9 & $\begin{array}{l}1980 \text { Convention on Certain Conventional } \\
\text { Weapons }\end{array}$ & 121 & 5 \\
\hline 10 & 1993 Chemical Weapons Convention & 192 & 2 \\
\hline 11 & 1997 Ottawa Treaty & 161 & 1 \\
\hline 12 & 1998 Rome Statute & 123 & 31 \\
\hline 13 & 2008 Convention on Cluster Munitions & 98 & 29 \\
\hline
\end{tabular}

The picture shows that these GCs of 1949 have been signed by all the countries of the world, in this respect it can be declared as an universal instrument, and a satisfactory number of States have signed some important instruments, for example, AP I, AP II, CWC etc., but many instruments which are important for the achievement of goals of IHL have not been signed by many countries; on the other hand the number of signatory States is quite dissatisfactory but the increase of the number is essential for the implementation of IHL.

It is of great need that these documents must be signed and ratified by all the countries especially the powerful States. Ratification of IHL treaties is important especially at least for two purposes; firstly, IHL instruments have been designed mainly for the protection of victims of ACs and those who are not taking part in the hostilities and secondly, by ratification the States show its intention to implement IHL by 
incorporating IHL in the domestic law which is very much important for debarring the soldiers from grave breaches of IHL and ensuring compliance with certain rights recognized globally (ICRC, 2015:20). The grave importance of implementation of IHL lies on the ratification of the humanitarian treaties by the State, because ratification is the first step for the implementation of IHL. Although the Geneva Conventions have been achieved universally and its Additional Protocols of 1977 are among the most widely accepted legal instruments following the ratifications a big number of ratified States did not enact national laws incorporating the provisions of GCs and APs.

\section{International Law compliance obligations}

Under the maxim "pacta sunt servanda" the State Parties of the international treaties, conventions and contracts are required that they must respect international law. The parties of the four GCs of 1949 and the APs have taken responsibilities to respect and to ensure respects of these instruments (common article 1, GCs 1949). The common article 1 is, "The High Contracting parties undertake to respect and to ensure respect for the present conventions in all circumstances." It is the first international treaty where the provision "to undertake to respect and to ensure respect in all circumstances" has been inserted but prior to these Conventions the term "respected in all circumstances" can be found in article 25(1) of "The Geneva Convention for the Protection of Wounded and Sick of 1929" and in article 82(1) of "The Geneva Convention Relative to the Treatment of Prisoners of War of 1929".

After the adoption of the GCs in 1949 in many documents the identical provision of common Article 1 can be found in article 1(1) of the AP I, 1977 and in article 1(1) of the AP III, 2005, and article 38(1) of "1989 the Convention on the Rights of the Child". This provision was accepted by the International Court of Justice (ICJ) in many cases, for example, the Nicaragua Judgment, the Nuclear Weapons and W all Advisory Opinions, by declaring it as customary international law. Now this common article 1 is deemed as "quasi-constitutional" international law which is based on erga omnes doctrine and it obliges the contracting parties to take necessary variety steps for persuading the States and private individuals to follow the GCs (Focarelli, 2010:125).

The term respect was used in many conventions in "individualcompliance meaning", for example, articles 15(1), 17(1)(3), 19(1)(2), 34(1), 35(2), 45, and 48 of the First Geneva Convention; to Arts 18(1), 20(1), 46(1), 49 of the Second Geneva Convention; to Arts 20(2), 29(1), 44(2), 46(3), 48(3), of the Third Geneva Convention; and to Arts 24(1), 25(2), 
39(2), 40(2), 49(3), 51(2), 55(2), 93(1), 94(1) and 94(145) of the Fourth Geneva Convention, art. 48, 80(2), 12(4), 33(3), 90(1)(d), and 90(6) of Additional Protocol 1, 1977. It means that the State shall adopt all the necessary measures to implement the conventions within their legal systems and the term ensure respect used in a broader sense in "Statecompliance meaning" which imposes an obligation on the States to take every possible step to induce the violator States to abide by the Conventions (Focarelli, 2010:125). This extensive approach of the term "ensure respect" has unequivocally been supported by the ICRC Commentaries to the GCs of 1949 and its APs (Pictet, 1952:1960).

The ICRC commentary of 1977 AP 1, mentions that the term "ensure respect" imposes an obligation on combatants, other armed forces members and civilians and civilian population as a whole to ensure respect for the conventions and protocols (Commentary on APs and GCs' 1987). The similar term has also been used in many other international instruments, i.e., article 1 of "The European Convention on Human Rights 1950", art. 1(1) “American Convention on Human Rights 1969" and the same meaning was given by the commentators, regional courts (Ilascu and Others v. Moldova and Russian Federation) and the International Court of Justice.

In 1993, the ICJ in its order on Bosnia v. Serbia case wondered whether the obligation of the State parties to prevent the genocide as set out in article 1 of "1948 Convention on the Prevention and Punishment of Genocide Crimes", goes beyond the territorial limit. The article 1 imposes the responsibilities on the State parties to haul genocide within and beyond the territory. Beyond the territory means that the State should steps to prevent genocide even when it is committed outside the territory.

Most of the States are reluctant to accept this meaning and obligation. For example, the Argentine Law of War Manual of 1989 provides that "the Geneva Conventions and Protocol I expressly oblige States not only to respect . . . , but also to ensure respect by issuing orders and instructions for that purpose." According to the Australian Commanders' Guide of 1994 "Australia is responsible for ensuring that its military forces comply with Law of Armed Conflict (LOAC) and all Australian Defence Force (ADF) members are responsible for ensuring that their conduct complies with the LOAC." Pursuant to the 1990 Military Manual, in the Soviet Union, all States, public organizations and by their citizens including armed forces members are bound to confirm respecting the law of hostilities (Focarelli, 2010:125).

In all these national documents, the term ensures respect was explained to indicate the individual compliance against the State-compliance 
concept. The State-compliance concept will be more helpful to implement so the State parties of Geneva Conventions need to make national legislations inserting both the concept of individual compliance and State compliance and the States those who have already enacted State legislation incorporating only the individual compliance, also need to include the concept of State compliance.

\section{Translation of the conventions and protocols into the mother languages}

English and French are recognized as the official versions of the GCs of 1949 (Art. 55, GC I) whereas the two APs are found in Arabic, English, Chinese, French, Spanish and Russian six official languages (Art. 102, AP I of 1977). The States parties whose national languages are different from the above ones are under the obligation to translate the text into their mother language, so that the nationals can easily understand the conventions and protocols and abide by them. The Geneva Conventions impose another important obligation to communicate these translations to the other contracting parties in peace time to avoid the difficulties on interpretation of translations by various countries in many ways (Articles 48, 49,128 and 144 respectively first, second and third and fourth Geneva Conventions, 1949).

\section{Dissemination of the conventions and protocols}

Knowledge is the prerequisite to show respect to any law. The disseminating the Geneva Conventions and Protocols to the general people and military personnel in various ways is considered an effective way of acquainting the people with these laws. All the Geneva Conventions and their Additional Protocols impose on every member State an obligation to disseminate widely the Conventions and the Protocols to the people during both peace and armed conflicts so that the members of armed forces and general people being well acquainted with these texts (arts. 47, 48,127 and 144 of respectively GCs I, II, III, IV).

\section{Advisers in the armed forces}

The parties of the protocols are asked to appoint necessary legal advisors in armed forces at peace time to ensure their availability at conflicting time to advise the military commanders during conflict. Moreover it is also the responsibility of the conflicting parties to ensure legal advisors at the armed conflict for proper instructions to the combatants to ensure compliance of the provisions of Conventions and Protocols during the conflict (art. 82, AP I of 1977). 


\section{Adopting criminal legislation}

One of the explicit obligations of the State parties of the GCs of 1949 and the APs 1977 is to enact necessary national legal framework to ensure proper prosecution and punishment of every individual for violation of IHL. Several articles, for example, articles 49-54, GC I; articles 146-149, GC IV and articles 85-89, AP I, expressly set forth the breaches which are to be repressed by punishment of liable individuals. The distinctive feature of those breaches is that the perpetrators or violators of such breach must be prosecuted and tried by impartial tribunal without considering their place of birth, nationality and positions (Pfanner, 2009:284).

The provision of prosecution and punishment of individual for violation of IHL is an important development in the implementation of IHL. Mentionable that "the ad hoc Criminal Tribunals for the former Yugoslavia and for Rwanda;" and ICC at Hague have set up examples of punishment of violator in both national and international level. The ICRC highlights that to ensure effective repression of grave breaches by the national court, the State shall have to adopt legislation taking into consideration a lot of issues namely, trial procedure; modes of punishment; modes of individual criminal responsibility and so on (ICRC, 2008: 29).

\section{Establishment of hospital zones, non-defended localities and demilitarized zones}

It was earlier stated that the main purpose of GCs and its Protocols is to protect those who do not take part in the hostilities. To achieve this object, the State parties are to take some steps, among them to establish hospital zone, non-defended localities and demilitarized zone are most important steps, as art. 60 (2) of the Additional Protocol 1 imposes a duty on the contracting parties to enter into an express agreement conferring certain area the status of demilitarized zone where attack is clearly prohibited and such agreement can be made either during peace time or in time of conflict (art. 60.2. of AP I). It is important to specify such areas and to make the agreement during peace time for better compliance of the conventions. Article 59 of Additional Protocol 1 further sets out that the parties, for the protection of the protected persons, can take mutual decision to establish non-defendable localities which are protected from attack by any means by any party to the conflict (art. 59 of AP I). 


\section{Establishment of national societies}

The importance of establishment of national societies was realized earlier back to 1929 when "the Convention for the Amelioration of the Condition of the Wounded and Sick in Armies at Field 1906, as revised in 1929", was drafted inserting the provision of protection of the aid societies formed in the State working voluntarily namely national Red Cross (RC) and Red Crescent (RC) societies established with the approval of their governments (arts. $10 \& 11$ ). Realizing the importance of the national societies, the Diplomatic Conference on the Treatment of the Prisoner of War, in its final Act. expressed as follows:

The Conference, recognizing the importance of the contribution demanded of National RC Societies and the Voluntary Aid Societies in promoting fellowship between nations, considers it highly desirable that, as far as it may be consistent with municipal law, they should be granted all possible facilities and exemptions for their work in time of peace, particularly as regards accommodation, free passage of personnel and property, and their relief activities.

Later on, in all important documents of IHL especially in four GCs of 1949 and its Protocols of 1977, the features of the national societies have been included. The first (arts. $26 \& 44$ ), second (art. 24) and third (art. 26) Geneva Conventions have implicitly discussed the features of National Societies but it was expressly discussed in the GC IV of 1949. As article 30 of fourth Geneva Convention says: "the protected persons shall have all the facilities for making application to the protecting power, the International Committee of the Red Cross, the national RC, RC, Red Lion and Sun societies of the countries where they may be." Article 63, lastly, States; "Subject to temporary and exceptional measures imposed for urgent reasons of security by the Occupying Power: a) Recognized National Societies shall be able to pursue their activities in accordance with RC Principles, as defined by the International Red Cross Conferences; b) The Occupying Power may not require any changes in the personnel or structure of these societies, which would prejudice the aforesaid activities."

After this international recognition of the National Societies, many countries of the world with the help of the Committee of the Red Cross and Red Crescent, formed their national societies in the light of the principles of the International Red Cross and Red Crescent Movement and at the initial stage of the studies of the APs many National Societies expressed their intention regarding inserting a new provision in the Protocol. The ICRC, considering it the best time for submitting their proposal in the 22nd International Conference of the Red Cross 1973, having examined the drafts additional protocols of the GCs, made a draft 
No. XV especially on the National Societies. From this conference it was requested to convene a Diplomatic Conference, consequently it was convened in Geneva in 1974 (Pictet, 1987:938). The Conference held in Geneva between 1974 and 1977 and most important two international documents on IAC and NIAC have been adopted in this conference. The AP I of 1977 inserted article 81 recognizing the National Societies. Now almost in every country, there is either Red Cross or Red Crescent Societies but the problem is that they are not fully independent from the government influence; as a result they are to face some problems in acting according to the principles during armed conflicts.

\section{Establishment of national commission for IHL}

The setting up of a national commission for IHL is neither required by the GCs nor by their APs. The Conventions represent the essential guarantees for the victims of armed conflict as laid down in the GCs that the State is coming forward for the satisfaction of its obligations regarding "to respect and to ensure respect" of the GCs and Protocols (ICRC, 2001:2). Statistic shows that over 100 States have established national committees in various names which play a key role in various ways in promotion and implementation of IHL at national level. They also keep continue their endless effects for the promotion of humanitarian knowledge in numerous strategies, for example, persuading the government for incorporation of humanitarian law in the national curriculum, suggesting for making necessary policies for proper dissemination of the Conventions and Protocols among the people and arranging necessary training programs and so on (ICRC, 2001:1).

\section{Formation of civil defense organizations}

The Addition Protocol of 1977 obligates the State parties to establish civil defense organizations in every State for the protection of the civilians from dangers of the AC, for providing necessary assistance to civilian population for protecting them from the results of conflicts and for ensuring the condition necessary for their survival (art. 61.a. of AP I). With a view to achieve these objectives the personnel authorized by the State to perform the civil defense are required to do some essential activities which are mainly: i) Warning the civilian population with respect to the forthcoming attacks; ii) constructing and organizing the shelters for the civilians so that they can be accommodated and protected from the effects of hostilities during the armed conflicts; iii) conducting rescue operation both during armed conflict and after the end of the conflict and it may be in different forms depending on the existing situations either 
searching the persons in the destroyed territory or conducting an operation consisted of medical personnel to provide first aid for wounded persons and to collect them from the battle field for ensuring the treatments and foods.

Along with the above activities, the civil defense organization is to do some other activities, for example, managing urgent shelter and supplies; providing immediate aid and medical care, helping in the restoration of peace in war torn area; and repairing the most essential utilities and speedy transfer of the dead bodies.

The above mentioned activities of the civil defense organizations indicate that this body can do a lot of work during armed conflict, before the conflict and after the end of the conflict but unfortunately this body has not been established in most of the countries. If a civil defense organization is formed, it can contribute greatly to minimize the suffering of the victims of the conflicts and in many cases many civilians can be protected from the effects of the hostilities.

\section{Ensuring the protection of the recognized emblems}

Long before the establishment of the Red Cross, during armed conflicts, there was a practice of marking the hospitals and ambulances by a flag of a single color to protect those from attacks of opposite party. At the historic International Conference in 1863, on the suggestion of General Durfour, the Red Cross on a white ground was recognized as the uniform visible distinctive emblem (art. 8. L. AP I) for marking hospitals and ambulances. The Swiss government convened the Diplomatic Conference in the following year and succeeded to sign "the Geneva Convention for the Amelioration of the Condition of the Wounded in Armies in the Field 1864" which officially recognized the Red Cross as a uniform emblem.

Turkey in her first war with Serbia and later on with Russia in 1876 notified the Swiss Federal Council that her Medical service would display the Red Crescent not Red Cross, although in 1865 Turkey had adhered Geneva Convention without any reservation. Later on some other countries like Siamese (Thailand) and Persian (Iran) asked for the recognition of the Red Lion and Sun and Israel proposed for using the red Shield of David as their protective emblems but it was not accepted as article 41 says, "under the direction of the competent military authority, the emblem of the red cross on a white ground shall be displayed on the flags, armlets and on all equipment employed in the Medical Service. Nevertheless, the countries which have already been using the Red Cross, the Red Crescent or the red lion and sun on a white ground as the protective emblem in place of Red Cross, have been recognized by the 
terms of the present Convention (art. 41, GC II)." Very recently in 2005 the claim of Israel was also accepted by the $3^{\text {rd }}$ Additional Protocol (Art. 2). Some other emblems, signs and signals namely the Red Cross, Red Crescent, red lion and sun on white (art. 38, GC IV arts 3 \& 4, AP I), distinctive signals (AP I, annex I, Chap. III), signs marking works and installation containing dangerous forces (art. $16 \& 56$ and annex I, chap. VI, AP I) and international distinctive sign for civil defense (art. 66, AP I) have been created and protected under the GCs and protocols and the flag of truce and emblem of cultural property have also been referred in the protocol.

The High Contracting Parties are under an obligation under the GCs, AP and other international instruments to prevent the misuse and deliberately improper use of the recognized emblems, signs or signals by making national laws (art 45, $38 \& 18$ (8) of GC I, arts $38 \& 18(8)$, of AP I, art. 23(f) Hague Regulation 1899 arts 27 \& 28, GC1929) and each State party shall take initiative to recognize medical and religious personnel (art. 18.1. AP I), religious personnel and civilian medical personnel (art. 18.3. AP I), the distinctive emblem and distinctive signals used in medical units and transports (art. 18.2, AP I). Complying with this obligation many countries have already incorporated a provision in the national law or military manual prohibiting improper use of the emblem of the Red Cross or Crescent, yet in many countries the Red Cross or Crescent emblems are continually being misused both during armed conflict and peace time for perfidy or other purposes. An example is Nicaragua, where the contras used the Red Cross emblem in a helicopter to transport military supplies which is a grave breach of the IHL (Slim, 1989). And in many countries it can be seen that the emblem of the Red Cross or Crescent are randomly being used by the doctors, hospitals etc. At the New Delhi Conference of March 1977 it was revealed that many countries had not yet made law prohibiting the improper use and ensuring punishment for the offenders, and those who enacted laws are also reluctant to implement it. So it is urgent need to make national legislation prohibiting all types of misuse and improper use of the recognized emblems and making provision for severe punishment for the violators.

In addition to the above mentioned measures the States should take some other initiatives during peace time to implement IHL which are mainly, enacting national legislation for implementation of various IHL conventions and treaties, making prisoners ' camps, establishing national humanitarian committee and giving greater emphasis on IHL in drawing up programs of legal co-operation and training ('Draft Recommendation' 1999). The States are also required to ratify, if they have not already done 
so, APs I and II of 1977 to the GCs of 1949, and lift any reservations there may be to these instruments and ensure that all their obligations arising from these instruments are systematically reviewed and carried out. Most importantly in 2002 the ICC has come into function so the States should recognize the jurisdiction of this court.

\section{Conclusion}

There is no dream of utopian State where no violence exists and no precautionary measures are required for minimizing the effects of violence. This is a reality that goes back to the beginning of the existence human civilization even where the conflict was present and it is strongly supposed that it would continue till the end of human existence. In this situation the States need to take some peace time steps to avoid future AC and to minimize the sufferings of the victims and to protect the protected persons and objects during AC. The study finds that to meet these objectives, the first and foremost duty of all concerned States are to make core IHL documents familiar to the citizens of the country including armed forces members. Dissemination of the Conventions and Protocols, training the combatants and non-combatants and so on are crucial but not sufficient for making people acquainting with IHL. On the other hand, to provide safe place for the civilians, wounded, prisoners of war during armed conflict States should establish safety zone, non-defended localities, demilitarized zone, prisoners `camps and hospital zone from the vicinity of the military territory. Most importantly States need to make necessary national legislation containing the provisions of GCs and APs and other IHL documents especially prescribing the trial process and specific punishment of the violators of the Conventions and Protocols during conflict. For implementation of IHL it is also necessary to prohibit misuse and improper use of the recognized emblems, signs and signals. Lastly to make necessary enactment, to provide sufficient training to the members of armed forces and others, to make essential suggestions for further day to day development of IHL, to sign and ratify the Conventions and Protocols, to operate dangerous rescue operations, to evacuate the civilians in the safety area and to evaluate the existing laws. It is also essential to establish national societies, national committee or commission for IHL and to form civil defense organizations. 


\section{References}

Draft recommendations. (1999). Parliamentary committee of the Council of Europe.

Draper, G. I. A. D. (1979). The implementation and enforcement of the Geneva Conventions of 1949 and the two Additional Protocols of 1977 (Vol. 164). The Hague Academy of International Law, (pp. 9-30).

Focarelli, C. (2010). Common Article 1 of Geneva Conventions 1949: A soap bubble. The European Journal of International Law, 21(1), 125.

International Committee of the Red Cross (ICRC). (2001). National Committees for the Implementation of International Humanitarian Law, P.2.

International Committee of the Red Cross (ICRC). (2008). How is the term "Armed Conflict" defined in International Humanitarian Law? ICRC opinion paper (p.1).

International Committee of the Red Cross (ICRC). (2015). Treaties, state parties and commentaries. Retrieved October 23, 2015, from https://www.icrc.org/applic/ihl/ihl.nsf/vwTreaties1949.xsp

International Committee of the Red Cross and Red Crescent (ICRC). (2015). The Domestic Implementation of International Humanitarian Law. A Manual, p.20.

Murphy, R. (2004). Contemporary Challenges to the Implementation of International Humanitarian Law. Connections: The Quarterly Journal, 3(3), 99114.

National Implementation of International Humanitarian Law (NIIHL). (2010). International Review of the Red Cross, 92(879), 47.

Pfanner, T. (2009). Various mechanisms and approaches to implementing international humanitarian law and protecting and assisting war victims. International Review of the Red Cross, 91(874), 279-328.

Pictet, J. (1987). Commentary on the additional protocols of 8 June 1977 to the Geneva Conventions of 12 August 1949. Geneva: Martinus Nijhoff Publishers.

Pictet, J. (ed.). (1952). Commentary - I Geneva Convention for the Amelioration of the Condition of the Wounded and Sick in Armed Forces in the Field. Geneva: International Committee of the Red Cross.

Rajon, S. (2008, June). International criminal responsibility. Paper presented in ICRC regional teachers training program, Dhaka.

Sandoz, Y. (1997). Implementing international humanitarian law. In M. K. Balachandran, \& V. Rose (Ed.), Introduction to International Humanitarian Law (p.250). New Delhi, India: International Committee of the Red Cross.

Slim, H. (1989). Protection of the Red Cross and Red Crescent emblems and the repression of misuse. In International Review of the Red Cross Archive, 29(272), 420-437. 


\section{Statutes and International Instruments}

Convention for the Prevention and Punishment of Terrorism, 19 League of Nations, OJ 23 (198): League of Nations Doc. C.546 (I).M383 (I) $1937 \mathrm{~V}$ (1938) 16 November 1937.

Convention for the Protection of Cultural Property in the Event of Armed Conflict, 14 May, 1954, The Hague,

Geneva Convention (I) for the Amelioration of the Condition of the Wounded and Sick in Armed Forces in the Field of 12 August 1949, 75 UNTS 31 (entered into force 21 October 1950).

Geneva Convention (II) for the Amelioration of the Condition of the Wounded and Sick and Shipwrecked Members of Armed Forces at Sea of 12 August 1949, 75 UNTS 31 (entered into force 21 October 1950).

Geneva Convention (III) Relative to the Treatment of Prisoners of War of 12 August 1949, 75 UNTS 31 (entered into force 21 October 1950).

Geneva Convention (IV) Relative to the Protection of Civilian Persons at Time of War of 12 August 1949, 75 UNTS 31 (entered into force 21 October 1950).

Convention II with Respect to the Laws and Customs of War and its annex: Regulations concerning the Laws and Customs of War on Land. The Hague, 29 July 1899.

Protocol Additional (I) to the Geneva Conventions of 12 August 1949, and Relating to the Protection of Victims of International Armed Conflicts, 1125 UNTS 3, 8 June 1977 (entered into force 7 December 1978).

Protocol Additional (II) to the Geneva Conventions of 12 August 1949, and relating to the Protection of Victims of Non-International Armed Conflicts, 1125 UNTS 3, 8 June 1977 (entered into force 7 December 1978).

Additional Protocol 111: Protocol Additional to Geneva Convention of 12 August, 1949, and Relating to the Adoption of Additional Distinctive Emblems, 2005

Rome Statute of the International Criminal Court, UN Doc. A/CONF.183/9, 17 July 1998 (entered into force 1 July 2002) 
126 IIUC Studies, 14(2)

\section{List of Cases}

Ilscu and others v. Moldova and Russia, 4878/99, Council of Europe: European Court of Human Rights, 8 July 2004, available at: http://www.refworld.org/cases,ECHR,414d9df64.html [accessed 19 February 2018

Nicaragua v. US of America, (Merits), Judgment, 27 June 1986, ICJ Rep. 14

Wall Advisory Opinion, 9 July 2004, ICJ Rep. 131

\section{Corresponding author}

Mohammad Saidul Islam can be contacted at: islamm.saidul@yahoo.com 